\title{
Seasonal and size-related differences in diet of the Atlantic angel shark Squatina dumeril in the northeastern Gulf of Mexico
}

\author{
Ivy E. Baremore ${ }^{1,2, *}$, Debra J. Murie ${ }^{1}$, John K. Carlson ${ }^{2}$ \\ ${ }^{1}$ University of Florida, Program of Fisheries and Aquatic Sciences, School of Forest Resources and Conservation, \\ 7922 NW 71st St, Gainesville, Florida 32653, USA \\ ${ }^{2}$ Present address: NOAA Fisheries Service, Southeast Fisheries Science Center, 3500 Delwood Beach Road, Panama City, \\ Florida 32408, USA
}

\begin{abstract}
Atlantic angel sharks Squatina dumeril were collected for stomach contents $(\mathrm{n}=437)$ from November 2002 through April 2005 from a butterfish Peprilus burti bottom trawl fishery in the northeastern Gulf of Mexico. Teleost fishes, especially Atlantic croaker Micropogonias undulatus, butterfish, and goatfishes (Mullidae), dominated the diet of Atlantic angel sharks and were the most important prey items for sharks of all sizes (305 to $1160 \mathrm{~mm}$ total length). Squid (Loligo sp.) were also important prey for all shark sizes, though they became less important with increasing shark size. Crustaceans like mantis shrimp Lysosquilla sp., brown rock shrimp Sicyonia brevirostris, and portunid crabs (Portunidae) were also eaten by angel sharks of all sizes in all seasons sampled. Seasonal differences in diet were detected with niche breadth, which was narrowest in winter and broadest in fall. Niche breadth was also size related and narrowed with increasing shark size. Size of prey was also related to shark size, with sharks mostly consuming prey $<30 \%$ of their total length and prey with body depths $<60 \%$ of their gape width.
\end{abstract}

KEY WORDS: Diet · Size-related feeding · Niche breadth · Angel shark · Squatina dumeril · Elasmobranch Resale or republication not permitted without written consent of the publisher

\section{INTRODUCTION}

Quantification of diet is essential for recognizing the roles of predators in an ecosystem. Analysis of diet can give indications of many factors, including prey preference (Baremore et al. 2008) and the movement of predators and prey, and can also reveal how an animal might respond to changes in its habitat and prey assemblage (Hambright 1994, Juanes et al. 2001). Basic trophic data also provide the foundation for ecosystem-based management, and a multi-species approach to fisheries management (Brodziak \& Link 2002, FAO 2003, Browman \& Stergiou 2004). Although knowledge of diet of top predators is important for understanding ecosystem dynamics, it is relatively poorly known for many species of elasmobranch, including angel sharks (Vogler et al. 2003).
Diet and prey preference of predators are affected by many factors, including predator size and size and availability of prey. For example, angel sharks eat prey whole (Fouts \& Nelson 1999), which functionally limits the size range of potential prey (Gill 2003). Selectivity of prey size by predators may be related to habitat, morphological specializations, and spatial overlap with prey items (Greene 1986). Size-related shifts in diet are common among marine fishes, including elasmobranchs (Stillwell \& Kohler 1982, Cortés \& Gruber 1990, Lowe et al. 1996, Ebert 2002). Differences in diet among fish of different sizes are often indications of changes in morphology and ability to capture prey, but larger predators may also be exposed to a wider range of potential prey than smaller predators (Juanes 1994).

The Atlantic angel shark Squatina dumeril is a demersal, deep-water species that ranges from nearshore 
to a maximum depth of $1400 \mathrm{~m}$ (FAO 2002) in the Gulf of Mexico and western Atlantic Ocean. Of the approximately 18 extant species of angel sharks, $S$. dumeril is one of up to 3 species thought to live in the Gulf of Mexico (FishBase v.2008, available at www.fishbase. org). Some information on life history and diet is available for other squatinid sharks (Ellis et al. 1996, Bridge et al. 1998, Fouts \& Nelson 1999, Brickle et al. 2003, Vogler et al. 2003), particularly the Pacific angel shark S. californica (Natanson \& Cailliet 1986, 1990, Cailliet et al. 1992), but very little information is available for the Atlantic angel shark (Gordon 1956). Previous studies have found that squatinids are top-level (trophic level $=4.1$ out of 5) ambush predators (Cortés 1999, Fouts \& Nelson 1999) that feed mostly on teleost fishes, cephalopods, and crustaceans (Ellis et al. 1996, Bridge et al. 1998, Vogler et al. 2003), and they may be nocturnal (Fouts \& Nelson 1999). The diet of Atlantic angel sharks is known from only 1 anecdotal account of 1 shark captured in New England that had remains of many fishes in its stomach (Gordon 1956). Although little is known about the life history and movement patterns of the Atlantic angel shark, there is some evidence that, unlike other shark species in the Gulf of Mexico which are apparently declining, angel sharks are increasing in abundance (Shepherd \& Myers 2005). Therefore, their role as a top predator in benthic and epi-benthic ecosystems could make them an important factor in the dynamics of the environment of the Gulf of Mexico (Hambright 1994, Yodzis 1994, Juanes et al. 2001).

Our objectives were to: (1) quantify the diet of Atlantic angel sharks, (2) determine if their diet changes with season or shark size, and (3) describe the relationship between the size of prey consumed by angel sharks relative to their size.

\section{MATERIALS AND METHODS}

Fish collections. Angel sharks Squatina dumeril were collected from butterfish trawlers landing their catch in Port St. Joe, Florida, USA, from November 2002 through April 2005. For each fishing trip, the entire catch was stored in a hold aboard the vessel upon capture and frozen until it was offloaded at the fish house. Most angel sharks were collected from an ice-water slurry as they were unloaded from the boats and were then packed in ice for transport to the laboratory. On rare occasions, sharks were set aside on ice at the fish house for several hours until they could be collected. Precaudal (length from the tip of the nose to the notch at the base of the upper lobe of the caudal fin), fork, and total lengths (TL) were measured $( \pm 1 \mathrm{~mm}$ ) and sharks were weighed wet $( \pm 0.01 \mathrm{~kg})$. Gape width, which is the maximum lateral width of the mouth when opened, was also measured externally $( \pm 1 \mathrm{~mm})$ using a ruler. Stomachs were then removed and frozen for later analysis, and remained frozen for a period ranging from a few days to 2 yr. Most sharks were processed within 1 to $2 \mathrm{~d}$ of collection.

Stomach content analysis. Stomachs were thawed and individual prey items were separated and counted. Prey items were identified to the lowest possible taxonomic level using several keys, including Robins \& Carleton (1986) and McEachran \& Fechhelm $(1998,2005)$ for fishes, (FAO 2002) for squids, and Williams (1984) for crustaceans. A reference collection of prey species, including fish otoliths (Baremore et al. 2008), was also used to identify partially digested prey items (Murie \& Lavigne 1985, Jobling \& Breiby 1986). Hard parts of prey remains were then counted, and individual prey were weighed $( \pm 0.01 \mathrm{~g})$ and measured. Intact prey items were measured $( \pm 1 \mathrm{~mm})$ for $\mathrm{TL}$ (fishes), mantle length (squids), or carapace length (crustaceans), while other morphometric measurements, such as length of the vertebral column and body depth (BD), were taken for prey that were not whole. Intact and non-degraded otoliths were also measured $( \pm 0.1 \mathrm{~mm})$ and weighed. Individual prey items were assigned a digestion code from 0 (no digestion evident) to 6 (nearly completely digested and unidentifiable) (Berens \& Murie 2008). Prey items coded 6 were mostly degraded otoliths, fish backbones with no associated flesh or other hard parts, and partial squid beaks and were considered to be remnants of previous feeding events. Therefore, in order to reduce the inclusion of previously consumed prey items and the possibility of post-capture feeding in the trawl (code 0), we excluded prey items assigned 0 or 6 from the analyses.

We summarized composition of the diet by percent occurrence $(\% \mathrm{O})$, percent number $(\% \mathrm{~N})$, percent weight (\%W) (Hyslop 1980), and percent index of relative importance (\%IRI) (Pinkas et al. 1971). We back-calculated weight values to the original wet weight of the prey item (Murie 1995) when possible from regression equations detailed by Baremore (2007). We back-calculated weights to reduce underrepresentation of soft-bodied prey items, likely squid, that digest more quickly than teleosts, which digest faster than crustaceans (Berens \& Murie 2008). We calculated weight values for prey categories (e.g. teleosts, cephalopods, and crustaceans) using only identified prey items, whereas we calculated IRI values for those prey categories with $\% \mathrm{O}$ and $\% \mathrm{~N}$ values for all identified prey items. Values of \%IRI for prey categories are not equal to the sum of the \%IRI values for each prey type, because $\% \mathrm{O}$ is not an additive index. 
We divided angel sharks into 3 size categories of near-equal numbers of sharks to assess size-related changes in food habits: $<550 \mathrm{~mm}$ TL ( $\mathrm{n}=79$ ), 550 to $800 \mathrm{~mm}$ TL ( $\mathrm{n}=55)$, and $>800 \mathrm{~mm}$ TL $(\mathrm{n}=47)$. We refer to size classes as $A, B$, and $C$ for the smallest, middle, and largest classifications, respectively. Sizeselectivity of the trawl for angel sharks was unknown, but sharks were collected throughout their known size range (FAO 2002).

We used cumulative prey curves to assess the adequacy of the sample size in describing the diet overall, and for each size category. The order in which stomachs were examined was randomized 10 times, and the number of new prey items in each stomach per randomization was counted. A graph plotting the total number of stomachs versus the average number of new prey items found in each stomach was then generated. We considered diets to be well described when the prey curve approached an asymptote (Ferry \& Cailliet 1996), which was when the percent of new unique prey items in the diet in our study increased by $<5 \%$ over the last 10 stomachs analyzed.

Size- and season-related shifts in diet. We evaluated size-related changes in the diet of angel sharks by comparing Levin's standardized niche breadth index values (Krebs 1999a,b) among size categories. This index is defined on a scale from 0 (minimum niche breadth) to 1 (maximum niche breadth) (Krebs 1999a). We also assessed diet overlap among shark size categories with Morisita's index of similarity, $\mathrm{C}_{\lambda}$ (Krebs $1999 a, b)$, which is not biased by sample size or number of resources. Morisita's index ranges from 0 (no overlap) to slightly greater than 1 (high overlap). We calculated all indices using taxonomic identification to family by frequency to allow relative comparisons.

We compared diets of angel sharks collected during different times of the year to determine if diet varied by season. Seasons were established based on differences in average surface water temperatures in the northeastern Gulf of Mexico by month (www.nodc. noaa.gov/dsdt/cwtg/egof.html). Surface temperature differences were used to delineate seasons because temperatures were unavailable for the $200 \mathrm{~m}$ depth where the majority of angel sharks were caught. Although bottom temperatures are colder than surface temperatures, the trend in seasonal fluctuations tends to correspond with shallow water temperature changes with a small lag (He \& Weisberg 2002). We combined diets for consecutive months with similar temperatures and, on this basis, made seasonal comparisons between winter (January and February: $\mathrm{n}=74,59^{\circ} \mathrm{C}$ ), spring (March, April, and May: $\mathrm{n}=58,73^{\circ} \mathrm{C}$ ), and fall (October, November, and December: $\mathrm{n}=51,67^{\circ} \mathrm{C}$ ). We excluded stomachs collected in summer because samples were too small (August: $\mathrm{n}=3$ ). We also compared diet among seasons with Levin's standardized niche breadth and Morisita's index of similarity.

Finally, we used multivariate analysis to further clarify differences in the diets. Principal component analysis (PCA) biplots were created to visually assess sources of variation within size groups and seasons simultaneously. Diets were grouped into combined size class and season categories (i.e. Class A winter, Class A spring, Class A winter, etc.). Analysis was carried out using \%IRI values for prey items that contributed $\geq 5 \%$ IRI of the diet of angel sharks in at least one size group/season category.

Prey size. Portions of the trawl catch were sampled in February and April 2005 (Baremore et al. 2008) to estimate sizes of potential prey. Species-specific regression equations developed from the sampled catch (Baremore 2007) were used to back-calculate TL, BD, and wet weight for prey items recovered in stomachs that were not whole. We assessed differences in size of consumable prey relative to shark size and shark gape using regression analysis (e.g. linear, power, exponential, and logistic regressions). Angel shark gape was regressed as a function of shark TL to allow estimation of gape in sharks when it was not available. We selected the 'best fit' model based on the highest coefficient of determination $\left(\mathrm{r}^{2}\right)$ or adjusted $\mathrm{r}^{2}$, and assessment of the residual plots (Zar 1984).

We calculated prey size ratios (prey TL/shark TL and prey BD/shark gape) to determine if there was a relationship between prey size and shark size and gape. These relationships were assessed by using the maximum prey TL and prey BD ratio per stomach to investigate gape limitation. We also calculated size of prey items eaten as relative prey $\mathrm{BD}$ (\% of gape) by shark size category.

\section{RESULTS}

\section{Diet}

Of 437 stomachs of Atlantic angel sharks Squatina dumeril analyzed, 24 (5\%) were empty, 208 (48\%) had only remnants of prey left at the completion of digestion (code of 6$)$, and 18 (4\%) had stomach contents with codes of 0 , indicating that they probably had empty stomachs when caught. Overall, we excluded 16 butterfish in 7 stomachs with a code of 0 , while we excluded only 2 other undigested prey items in 2 stomachs (1 rough scad and 1 shortwing searobin Prionotus stearnsi). Roughly half of the collected stomachs in all months contained prey items that were assigned a code of 6 . The highest proportion (59\%) was in spring and lowest was in fall $(48 \%)$. The smallest sharks $(<500 \mathrm{~mm} \mathrm{TL})$ had the highest proportion of prey items 
coded 6 (as high as $73 \%$ ), and this proportion decreased with size.

At least 1 prey item was present in 187 (43\%) of the stomachs with a digestion code $>0$ and $<6$, and these stomachs were used in the analyses. The sharks included in the diet analysis ranged in size from 305 to $1160 \mathrm{~mm} \mathrm{TL} ; 88$ of them were females and 99 were males (Fig. 1A). All size categories of sharks were collected in the same locations and over all months (Fig. 1B). Cumulative prey curve analysis showed that diets were well described overall for Size Categories A and $\mathrm{B}$ (sharks $\leq 800 \mathrm{~mm} \mathrm{TL}$ ), with a 1.3 and $3.6 \%$ increase in new prey items over the last 10 stomachs analyzed (Fig. 2A,B). The diet of Size Category C
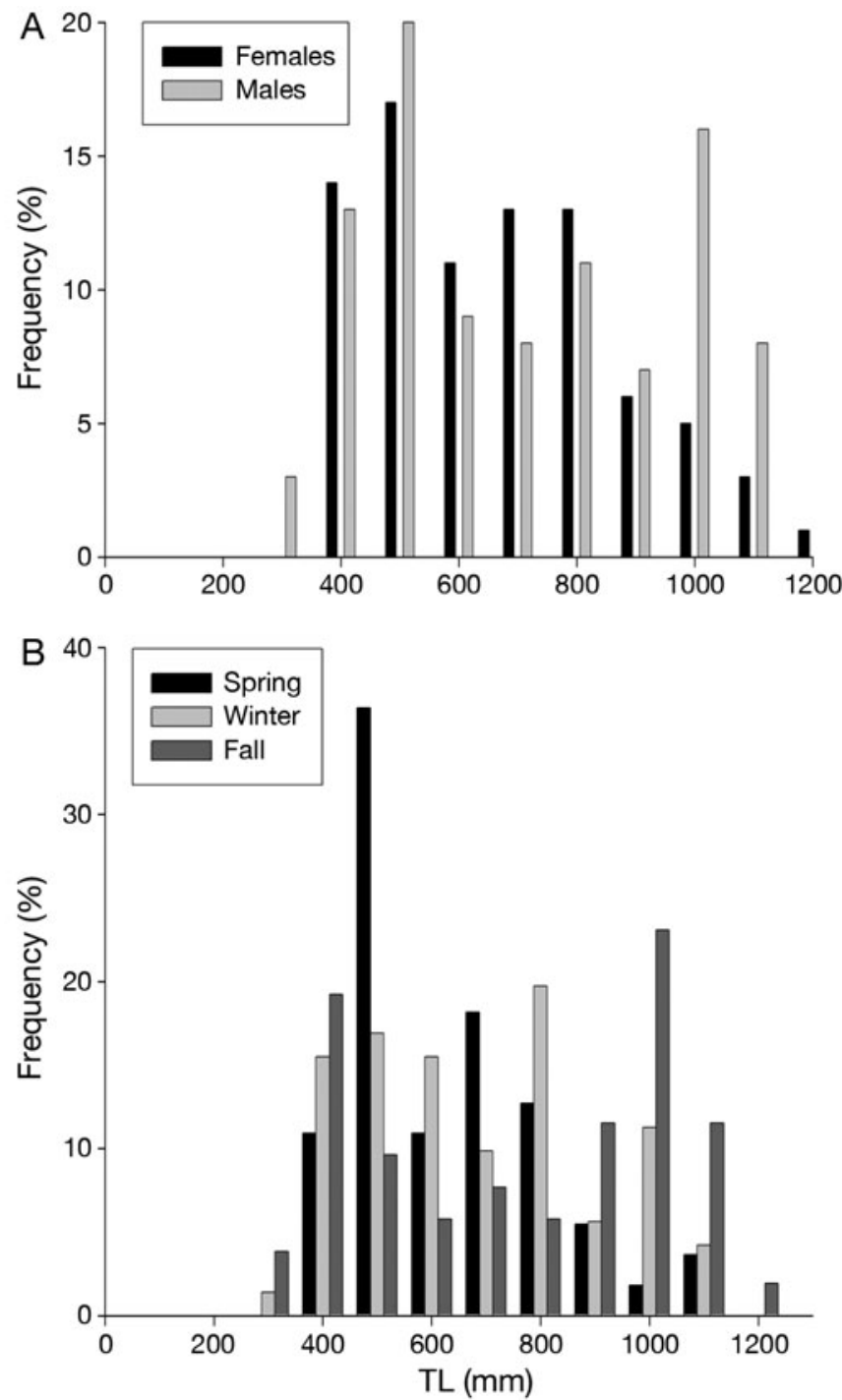

Fig. 1. Squatina dumeril. Size frequencies of Atlantic angel sharks with non-empty stomachs containing prey items (coded $>0$ and $<6$, see 'Materials and methods: Stomach content analysis'). (A) by sex and (B) by season (sharks >800 mm TL) was possibly not adequately described, as unique prey items increased $6.4 \%$ over the last 10 stomachs analyzed (Fig. 2C).

Teleost fishes dominated (93.4\%IRI) the diets of Atlantic angel sharks (Table 1). Atlantic croaker
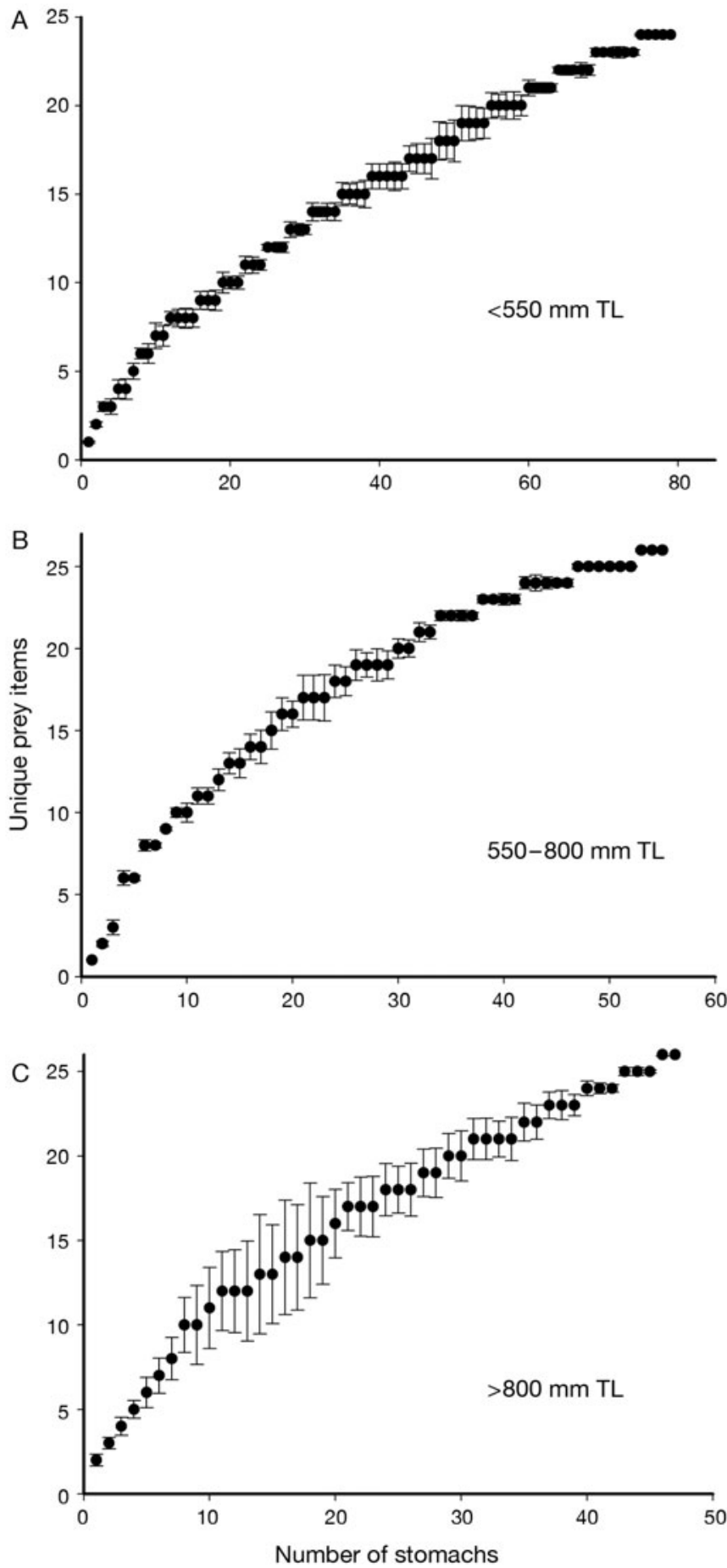

Fig. 2. Squatina dumeril. Cumulative prey curves for Atlantic angel sharks in Size Classes A-C (Panels A-C, respectively). Size ranges given in panels. TL: total length 
Table 1. Squatina dumeril. Diet of the Atlantic angel shark by occurrence $(\mathrm{O})$, percent occurrence $(\% \mathrm{O})$, number $(\mathrm{N})$, percent number $(\% \mathrm{~N})$, back-calculated weight $(\mathrm{W})$, percent weight $(\% \mathrm{~W})$, index of relative importance (IRI), and percent index of relative importance (\%IRI). Weight was not back-calculated for crustaceans and unidentified fishes; $\mathrm{n}=191$ non-empty stomachs, all sizes. Values in bold: indices calculated for overall prey categories

\begin{tabular}{|c|c|c|c|c|c|c|c|c|}
\hline Prey identification & $\mathrm{O}$ & $\% \mathrm{O}$ & $\mathrm{N}$ & $\% \mathrm{~N}$ & $\mathrm{~W}$ & $\% \mathrm{~W}$ & IRI & $\%$ IRI \\
\hline Teleosts & 145 & 81.0 & 224 & 77.0 & 7644.9 & 67.6 & 11715.3 & $93.4^{\mathrm{a}}$ \\
\hline $\begin{array}{l}\text { Anguilliformes } \\
\text { Acropomatidae }\end{array}$ & 7 & 3.9 & 7 & 2.4 & 98.0 & 0.9 & 12.8 & 1.1 \\
\hline $\begin{array}{l}\text { Synagrops bellus } \\
\text { Bothidae }\end{array}$ & 1 & 0.6 & 1 & 0.3 & 8.1 & 0.1 & 0.2 & $<0.1$ \\
\hline Syacium papillosum & 1 & 0.6 & 1 & 0.3 & 58.0 & 0.5 & 0.5 & $<0.1$ \\
\hline $\begin{array}{l}\text { Unid. flounder } \\
\text { Brotulidae }\end{array}$ & 3 & 1.7 & 3 & 1.0 & 114.5 & 1.0 & 3.4 & 0.3 \\
\hline $\begin{array}{l}\text { Brotula sp. } \\
\text { Carangidae }\end{array}$ & 1 & 0.6 & 1 & 0.3 & 85.0 & 0.8 & 0.6 & 0.1 \\
\hline $\begin{array}{l}\text { Trachurus lathami } \\
\text { Clupeidae }\end{array}$ & 3 & 1.7 & 3 & 1.0 & 137.5 & 1.2 & 3.8 & 0.3 \\
\hline $\begin{array}{l}\text { Etrumeus teres } \\
\text { Lutjanidae }\end{array}$ & 4 & 2.2 & 4 & 1.4 & 97.9 & 0.9 & 5.0 & 0.4 \\
\hline Rhomboplites aurorubens & 1 & 0.6 & 1 & 0.3 & 190.0 & 1.7 & 1.1 & 0.1 \\
\hline $\begin{array}{l}\text { Pristomoides aquilonaris } \\
\text { Mullidae }\end{array}$ & 6 & 3.4 & 6 & 2.1 & 312.6 & 2.8 & 16.2 & 1.4 \\
\hline Upeneus parvus & 2 & 1.1 & 4 & 1.4 & 278.6 & 2.5 & 4.3 & 0.4 \\
\hline Mullus auratus & 8 & 4.5 & 9 & 3.1 & 596.5 & 5.3 & 37.4 & 3.3 \\
\hline $\begin{array}{l}\text { Unid. goatfish } \\
\text { Ophidiidae }\end{array}$ & 2 & 1.1 & 2 & 0.7 & 98.9 & 0.9 & 1.7 & 0.2 \\
\hline $\begin{array}{l}\text { Lepophidium sp. } \\
\text { Percophidae }\end{array}$ & 4 & 2.2 & 5 & 1.7 & 157.2 & 1.4 & 6.9 & 0.6 \\
\hline $\begin{array}{l}\text { Bembrops anatirostris } \\
\text { Phycidae }\end{array}$ & 1 & 0.6 & 1 & 0.3 & 4.9 & $<0.1$ & 0.2 & $<0.1$ \\
\hline $\begin{array}{l}\text { Urophycis sp. } \\
\text { Polymixiidae }\end{array}$ & 7 & 3.9 & 7 & 2.4 & 291.1 & 2.6 & 19.5 & 1.7 \\
\hline $\begin{array}{l}\text { Polymixia sp. } \\
\text { Sciaenidae }\end{array}$ & 1 & 0.6 & 2 & 0.7 & 26.2 & 0.2 & 0.5 & $<0.1$ \\
\hline Micropogonias undulatus & 18 & 10.1 & 21 & 7.2 & 1505.6 & 13.3 & 206.5 & 18.0 \\
\hline Leiostomus xanthurus & 9 & 5.0 & 9 & 3.1 & 693.5 & 6.1 & 46.4 & 4.0 \\
\hline Cynoscion sp. & 1 & 0.6 & 1 & 0.3 & 150.0 & 1.3 & 0.9 & 0.1 \\
\hline $\begin{array}{l}\text { Scorpaenidae } \\
\text { Serranidae }\end{array}$ & 3 & 1.7 & 3 & 1.0 & 54.4 & 0.5 & 2.5 & 0.2 \\
\hline Serranus atrobranchus & 1 & 0.6 & 1 & 0.3 & 25.0 & 0.2 & 0.3 & $<0.1$ \\
\hline $\begin{array}{l}\text { Centropristis sp. } \\
\text { Sparidae }\end{array}$ & 6 & 3.4 & 6 & 2.1 & 216.8 & 1.9 & 13.3 & 1.2 \\
\hline Stenotomus caprinus & 12 & 6.7 & 14 & 4.8 & 481.0 & 4.3 & 60.8 & 5.3 \\
\hline $\begin{array}{l}\text { Lagodon rhomboides } \\
\text { Stromateidae }\end{array}$ & 1 & 0.6 & 1 & 0.3 & 65.0 & 0.6 & 0.5 & $<0.1$ \\
\hline $\begin{array}{l}\text { Peprilus burti } \\
\text { Synodontidae }\end{array}$ & 9 & 5.0 & 13 & 4.5 & 919.9 & 8.1 & 63.4 & 5.5 \\
\hline Saurida normani & 5 & 2.8 & 6 & 2.1 & 573.3 & 5.1 & 19.9 & 1.7 \\
\hline Unid. lizardfish & 3 & 1.7 & 3 & 1.0 & 311.3 & 2.8 & 6.3 & 0.6 \\
\hline $\begin{array}{l}\text { Synodus sp. } \\
\text { Triglidae }\end{array}$ & 1 & 0.6 & 1 & 0.3 & 9.5 & 0.1 & 0.2 & $<0.1$ \\
\hline Prionotus longispinosus & 1 & 0.6 & 1 & 0.3 & 62.8 & 0.6 & 0.5 & $<0.1$ \\
\hline Prionotus stearnsi & 1 & 0.6 & 1 & 0.3 & 21.6 & 0.2 & 0.3 & $<0.1$ \\
\hline Unid. teleosts & 67 & 37.4 & 86 & 29.6 & & & & \\
\hline Elasmobranchs & 1 & 0.6 & 1 & 0.3 & & & & \\
\hline Elasmobranch remains & 1 & 0.6 & 1 & 0.3 & & & & \\
\hline Cephalopods & 25 & 14.0 & 31 & 10.7 & 3606.1 & 31.9 & 594.4 & 4.7 \\
\hline Loligo sp. & 25 & 14.0 & 31 & 10.7 & 3606.1 & 31.9 & 594.4 & 51.7 \\
\hline Crustaceans & 34 & 19.0 & 35 & 12.0 & 50.1 & 0.4 & 236.9 & $1.9^{\mathrm{a}}$ \\
\hline Portunus spinicarpus & 1 & 0.6 & 2 & 0.7 & 14.7 & 0.1 & 0.5 & $<0.1$ \\
\hline Sicyonia brevirostris & 1 & 0.6 & 1 & 0.3 & 5.8 & 0.1 & 0.2 & $<0.1$ \\
\hline Sicyonia sp. & 2 & 1.1 & 2 & 0.7 & 4.8 & $<0.1$ & 0.8 & 0.1 \\
\hline Stomapoda & $\overline{9}$ & 5.0 & 9 & 3.1 & 24.8 & 0.2 & 16.7 & 1.4 \\
\hline Unid. crustaceans & 21 & 11.7 & 21 & 7.2 & & & & \\
\hline Total for overall categories & & & & & & & 12546.6 & \\
\hline Total & 179 & 100.0 & 291.0 & 100.0 & 11301.1 & 100.0 & 1148.9 & 100.0 \\
\hline
\end{tabular}


Micropogonias undulatus were the most important teleost prey overall (18.0\%IRI), followed by longspine porgy Stenotomus caprinus (5.3\%IRI), spot Leiostomus xanthurus (4.0\%IRI), butterfish Peprilus burti (5.5\%IRI), and red goatfish Mullus auratus (3.3\%IRI). Squid Loligo sp. was the most important single prey species in the diet of Atlantic angel sharks (51.7\%IRI), whereas crustaceans $(1.9 \%$ IRI) were of relatively minor importance.

Teleosts dominated the diets of sharks in all size categories (Table 2). By overall prey category, teleosts made up from 77 to $89 \% \mathrm{O}$ and from 72 to $83 \% \mathrm{~N}$ of the diets of sharks of all sizes. Crustaceans made up $\sim 8$ to $27 \% \mathrm{O}$ and 6 to $15 \% \mathrm{~N}$ of stomach contents, and squid were found in 12 to $17 \% \mathrm{O}$ and 10 to $13 \% \mathrm{~N}$ of stomachs. Within the smallest size group (A), however, squid $(63.0 \%$ IRI) was the most important single prey species in the diet (Table 2), followed by hake Urophycis sp. (9.1\%IRI), cusk eel Lepophidium sp. (7.2\%IRI), and seabasses (Serranidae) (4.3\%IRI). Atlantic croaker ( $25.7 \%$ IRI) and squid (27.9\%IRI) were the most common prey overall for sharks in Size Group B, followed by red goatfish (12.9\%IRI), longspine porgies (9.7\%IRI), and mantis shrimp Lysosquilla sp. (4.4\%IRI). Overall, croakers (Sciaenidae) and goatfishes (Mullidae) were the most common families by \% $\mathrm{N}$ and \%IRI represented in the diets of angel sharks in the smallest size category. The diet of the largest sharks (Size Category C) was dominated by butterfish $(28.9 \%$ IRI) and squid (40.4\%IRI), followed by Atlantic croaker (12.3\%IRI).

Squid was the most important prey for angel sharks collected in winter (40.9\%IRI), followed by Atlantic croaker $(25.7 \%$ IRI), and longspine porgies (8.2\%IRI; Fig. 3). Angel sharks collected in spring most frequently ate butterfish (47.3\%IRI), followed by squid (17.3\%IRI), Atlantic croaker (9.3\%IRI), and red goatfish $(8.9 \%$ IRI). Butterfish were also the most common prey in fall $(43.6 \%$ IRI). Squid were also frequently eaten $(33.2 \%$ IRI), as were shortjaw lizardfish Saurida normani (7.3\%IRI).

\section{Changes in diet with shark size and season}

Although teleosts were the most important component of the diets of all size categories of angel sharks (Table 2), there were differences in diet of different sized sharks, as indicated by niche overlap estimates. Morisita's index of similarity indicated that shark Size Classes A $(<550 \mathrm{~mm})$ and B (550 to $800 \mathrm{~mm} \mathrm{TL})$ were the most similar $\left(\mathrm{C}_{\lambda}=\right.$ 0.73), while $A$ and $C(>800 \mathrm{~mm} \mathrm{TL}$ ) were the least similar $\left(C_{\lambda}=0.43\right)$. Size Groups B and $C$ also had a high niche overlap value, with a Morisita's index of similarity of 0.66 . Niche breadth was narrowest for the largest angel sharks, with Levin's standardized niche breadth values of $0.50,0.55$, and 0.43 for Size Classes $\mathrm{A}, \mathrm{B}$, and $\mathrm{C}$, respectively.

Seasonal differences in diet also were detected, with winter and fall diets overlapping the least (Morisita's index $=0.72)$. Winter and spring $(0.83)$ overlapped the most, and spring and fall diets were the most similar (0.88). Levin's simplified niche breadth showed the narrowest niche for winter $(0.40)$, followed by spring, (0.48), and fall (0.63).

Principal Components (PC) 1 and 2 explained $84.0 \%$ ( $\mathrm{PC} 1=74.4 \%, \mathrm{PC} 2=9.6 \%)$ of the variance in the diet categories. When assessed simultaneously by size and season, PCA biplots showed that all angel sharks in Size Class A grouped (loaded) closely in all seasons, with squid being the most important prey overall (Fig. 4). There were differences in all seasons for Size Class B angel sharks, with sharks collected in fall grouping very closely with squid, while those in the spring and winter grouped more closely with a wider range of prey, especially Atlantic croaker, longspine porgy, and the goatfishes. Angel sharks in the largest size class (C) collected in the winter grouped closely with squid, and the fall and spring diets were more influenced by butterfish and spot.

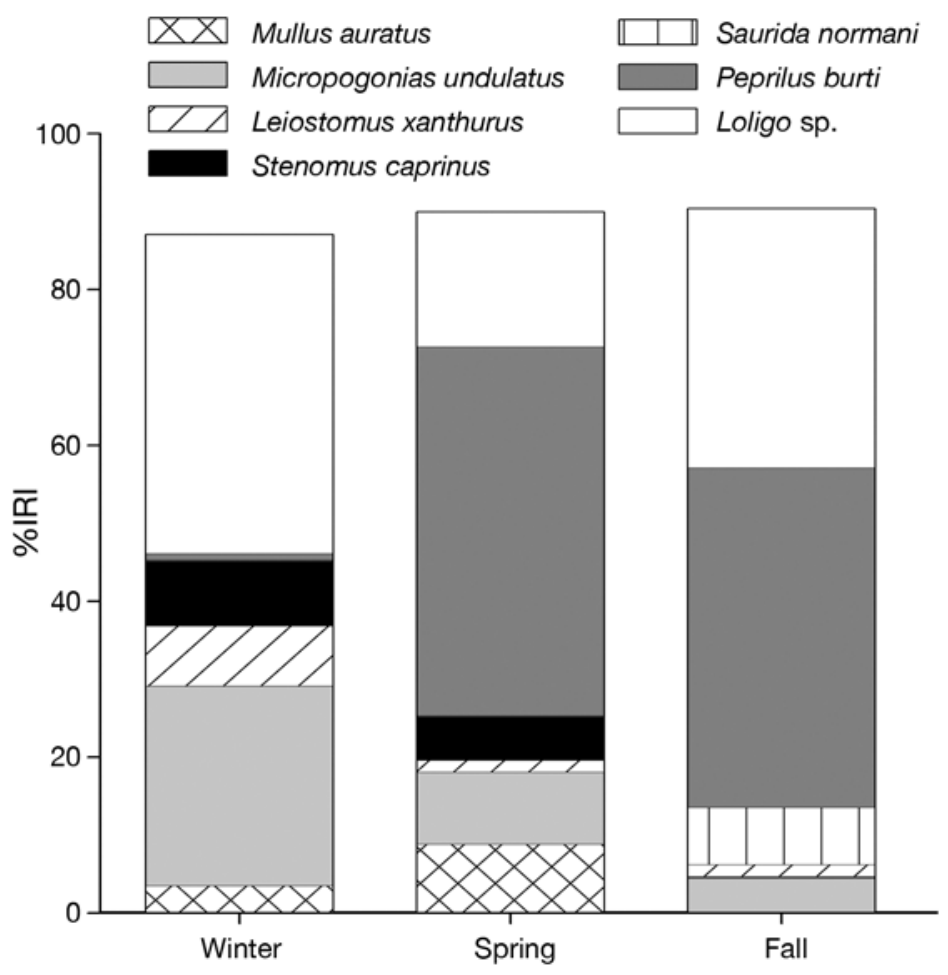

Fig. 3. Squatina dumeril. Composition of the diet of Atlantic angel sharks (index of relative importance, \%IRI) by season. Only prey items that were $>5 \%$ IRI in at least 1 season were included 
Table 2. Squatina dumeril. Diet for Atlantic angle sharks in Size Classes A (TL < $550 \mathrm{~mm}, \mathrm{n}=69)$, B $(550<\mathrm{TL}<800 \mathrm{~mm}, \mathrm{n}=67)$, and $\mathrm{C}(\mathrm{TL}>800 \mathrm{~mm}, \mathrm{n}=55)$, by $\% \mathrm{O}, \% \mathrm{~N}, \% \mathrm{~W}$, and \%IRI. Values in bold: indices calculated for overall prey categories

\begin{tabular}{|c|c|c|c|c|c|c|c|c|c|c|c|c|}
\hline \multirow[b]{2}{*}{ Prey identification } & \multicolumn{4}{|c|}{$\longrightarrow$ Size Class A -} & \multicolumn{4}{|c|}{ Size Class B } & \multicolumn{3}{|c|}{$\longrightarrow$ Size Class C } & \multirow{2}{*}{$\overline{\% \text { IRI }}$} \\
\hline & $\% \mathrm{O}$ & $\% \mathrm{~N}$ & $\% \mathrm{~W}$ & \%IRI & $\% \mathrm{O}$ & $\% \mathrm{~N}$ & $\% \mathrm{~W}$ & $\%$ IRI & $\% \mathrm{O}$ & $\% \mathrm{~N}$ & $\% \mathrm{~W}$ & \\
\hline Teleosts & 76.8 & 72.1 & 62.7 & $92.3^{\mathrm{a}}$ & 77.8 & 75.7 & 76.9 & $93.2^{\mathrm{a}}$ & 89.4 & 83.3 & 60.2 & $93.5^{\mathrm{a}}$ \\
\hline Anguilliformes & 4.3 & 3.5 & 0.5 & 1.9 & 1.6 & 0.9 & 0.2 & 0.1 & 6.4 & 3.3 & 1.5 & 1.5 \\
\hline Acropomatidae & & & & & & & & & & & & \\
\hline $\begin{array}{l}\text { Synagrops bellus } \\
\text { Bothidae }\end{array}$ & & & & & & & & & 2.1 & 1.1 & 0.1 & 0.1 \\
\hline Syacium papillosum & & & & & & & & & 2.1 & 1.1 & 1.1 & 0.2 \\
\hline Unid. flounder & & & & & 4.8 & 2.6 & 2.4 & 1.5 & & & & \\
\hline Brotulidae & & & & & & & & & & & & \\
\hline Brotula sp. & & & & & 1.6 & 0.9 & 1.8 & 0.3 & & & & \\
\hline Carangidae & & & & & & & & & & & & \\
\hline $\begin{array}{l}\text { Trachurus lathami } \\
\text { Clupeidae }\end{array}$ & & & & & 3.2 & 1.7 & 2.4 & 0.8 & 2.1 & 1.1 & 0.4 & 0.2 \\
\hline $\begin{array}{l}\text { Etrumeus teres } \\
\text { Lutjanidae }\end{array}$ & 1.4 & 1.2 & 1.2 & 0.4 & & & & & 6.4 & 3.3 & 1.6 & 1.5 \\
\hline Rhomboplites aurorubens & & & & & & & & & 2.1 & 1.1 & 3.5 & 0.5 \\
\hline $\begin{array}{l}\text { Pristomoides aquilonaris } \\
\text { Mullidae }\end{array}$ & 2.9 & 2.3 & 9.8 & 3.8 & 3.2 & 1.7 & 0.9 & 0.5 & 4.3 & 2.2 & 3.0 & 1.1 \\
\hline Upeneus parvus & & & & & 3.2 & 3.5 & 6.0 & 1.8 & & & & \\
\hline Mullus auratus & & & & & 11.1 & 7.0 & 12.1 & 12.9 & 2.1 & 1.1 & 0.6 & 0.2 \\
\hline Unid. goatfish & & & & & 1.6 & 0.9 & 1.0 & 0.2 & 2.1 & 1.1 & 0.9 & 0.2 \\
\hline $\begin{array}{l}\text { Lepophidium sp. } \\
\text { Percophidae }\end{array}$ & 4.3 & 4.7 & 10.5 & 7.2 & & & & & 2.1 & 1.1 & 0.7 & 0.2 \\
\hline $\begin{array}{l}\text { Bembrops anatirostris } \\
\text { Phycidae }\end{array}$ & & & & & & & & & 2.1 & 1.1 & 0.1 & 0.1 \\
\hline $\begin{array}{l}\text { Urophycis sp. } \\
\text { Polymixiidae }\end{array}$ & 4.3 & 3.5 & 15.7 & 9.1 & 4.8 & 2.6 & 2.1 & 1.4 & 2.1 & 1.1 & 0.3 & 0.1 \\
\hline $\begin{array}{l}\text { Polymixia sp. } \\
\text { Sciaenidae }\end{array}$ & 1.4 & 2.3 & 2.3 & 0.7 & & & & & & & & \\
\hline Micropogonias undulatus & 2.9 & 2.3 & 9.1 & 3.6 & 15.9 & 9.6 & 17.0 & 25.7 & 12.8 & 8.9 & 11.2 & 12.3 \\
\hline Leiostomus xanthurus & & & & & 9.5 & 5.2 & 10.4 & 9.1 & 6.4 & 3.3 & 3.8 & 2.2 \\
\hline Cynoscion sp. & & & & & 1.6 & 0.9 & 3.2 & 0.4 & & & & \\
\hline $\begin{array}{l}\text { Scorpaenidae } \\
\text { Serranidae }\end{array}$ & 4.3 & 3.5 & 4.9 & 4.0 & & & & & & & & \\
\hline Serranus atrobranchus & 1.4 & 1.2 & 2.2 & 0.5 & & & & & & & & \\
\hline $\begin{array}{l}\text { Unid. seabass } \\
\text { Sparidae }\end{array}$ & 4.3 & 3.5 & 5.5 & 4.3 & 4.8 & 2.6 & 3.3 & 1.7 & & & & \\
\hline Stenotomus caprinus & & & & & 11.1 & 7.0 & 7.4 & 9.7 & 10.6 & 6.7 & 2.4 & 4.7 \\
\hline Lagodon rhomboides & & & & & 1.6 & 0.9 & 1.4 & 0.2 & & & & \\
\hline Stromateidae & & & & & & & & & & & & \\
\hline Peprilus burti & & & & & & & & & 19.1 & 14.4 & 17.0 & 28.9 \\
\hline $\begin{array}{l}\text { Synodontidae } \\
\text { Saurida normani }\end{array}$ & & & & & & & & & & & & \\
\hline $\begin{array}{l}\text { Saurida normani } \\
\text { Unid lizardish }\end{array}$ & & & & & 3.2 & 1.7 & 3.3 & 1.0 & 6.4 & 4.4 & 7.8 & 3.7 \\
\hline Unid. lizardish & 1.4 & 1.2 & 0.1 & 0.2 & & & & & 4.3 & 2.2 & 5.7 & 1.6 \\
\hline $\begin{array}{l}\text { Synodus sp. } \\
\text { Triglidae }\end{array}$ & 1.4 & 1.2 & 0.8 & 0.3 & & & & & & & & \\
\hline Prionotus longispinosus & & & & & 1.6 & 0.9 & 1.3 & 0.2 & & & & \\
\hline Prionotus stearnsi & & & & & 1.6 & 0.9 & 0.5 & 0.1 & & & & \\
\hline Unid. teleosts & 44.9 & 41.9 & & & 28.6 & 24.3 & & & 38.3 & 24.4 & & \\
\hline Elasmobranchs & & & & & & & & & 2.1 & 1.1 & & \\
\hline Elasmobranch remains & & & & & & & & & 2.1 & 1.1 & & \\
\hline Cephalopods & 11.6 & 12.8 & 36.9 & 5.1 & 14.3 & 9.6 & 22.5 & 3.6 & 17.0 & 10.0 & 39.4 & 6.1 \\
\hline Loligo sp. & 11.6 & 12.8 & 36.9 & 63.0 & 14.3 & 9.6 & 22.5 & 27.9 & 17.0 & 10.0 & 39.4 & 40.4 \\
\hline Crustaceans & 18.8 & 15.1 & 0.4 & $2.6^{\mathrm{a}}$ & 27.0 & 14.8 & 0.5 & $3.2^{\mathrm{a}}$ & 8.5 & 5.6 & 0.4 & $0.4^{\mathrm{a}}$ \\
\hline Portunus spinicarpus & & & & & & & & & 2.1 & 2.2 & 0.3 & 0.3 \\
\hline Sicyonia brevirostris & & & & & & & & & 2.1 & 1.1 & 0.1 & 0.1 \\
\hline Sicyonia sp. & & & & & 1.6 & 0.9 & 0.1 & 0.1 & 2.1 & 1.1 & & \\
\hline Lysosquilla sp. & 2.9 & 2.3 & 0.4 & 0.8 & 11.1 & 6.1 & 0.4 & 4.4 & & & & \\
\hline Shrimp remains & & & & & & & & & 2.1 & 1.1 & & \\
\hline Unid. crustaceans & 15.9 & 12.8 & & & 14.3 & 7.8 & & & & & & \\
\hline Total for overall categories & & & & 11223.8 & & & & 12737.9 & & & & 13720.8 \\
\hline Total number & 69 & 86 & 1120.8 & 914.4 & 63 & 115 & 4681.3 & 1642.8 & 47 & 90 & 5417.0 & 2083.8 \\
\hline
\end{tabular}




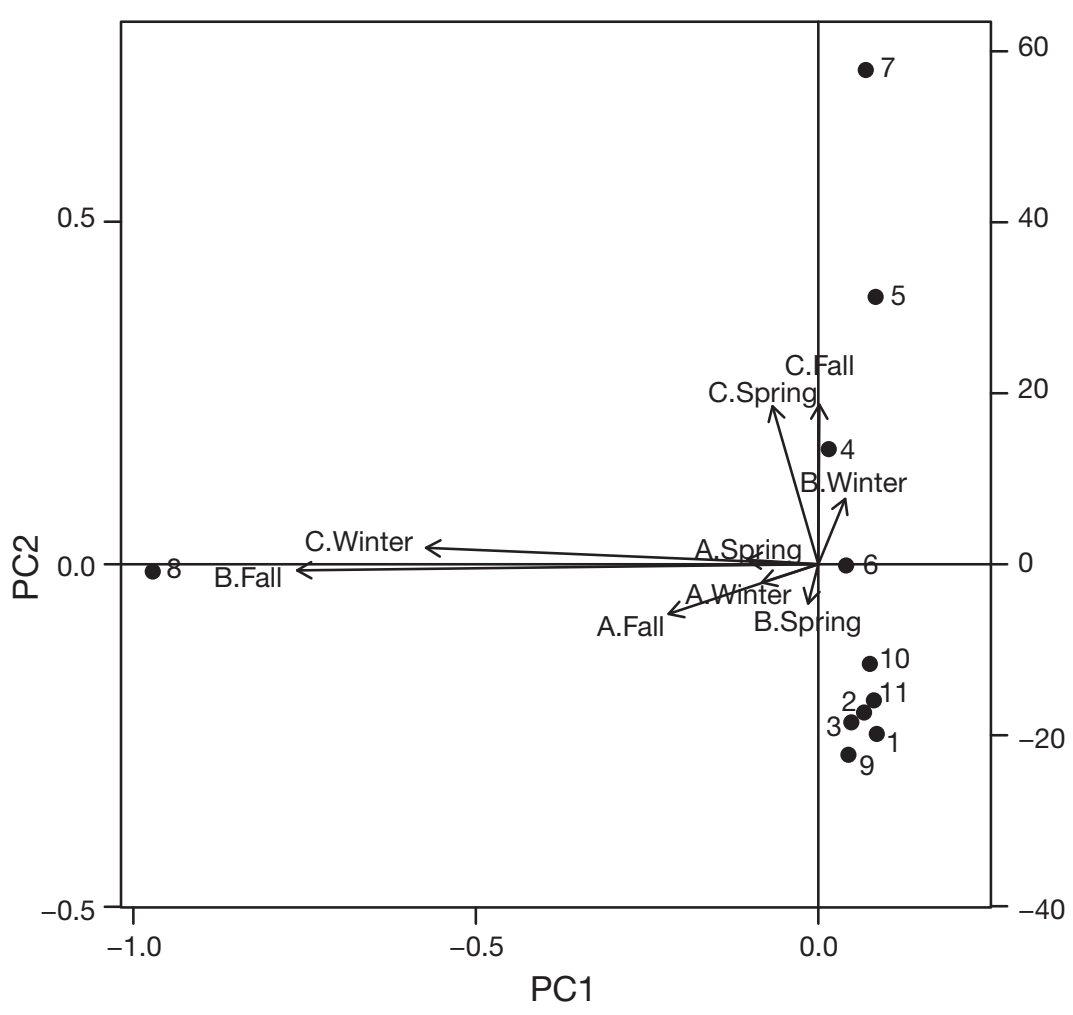

Fig. 4. Squatina dumeril. Principal component (PC) analysis biplots of scores calculated using \%IRI values for prey items $\geq 5 \%$ IRI for Size Classes A $(<550 \mathrm{TL})$, B (550 to $800 \mathrm{TL}$ ), and C (>800 mm TL) by season. Prey items are represented numerically-1: Mullus auratus; 2: Lepophidium sp.; 3: Urophysis sp.; 4: Micropogonias undulatus; 5: Leiostomus xanthurus; 6: Stenomus caprinus; 7: Peprilus burti; 8: Loligo sp.; 9: Pristipomoides aquilonaris; 10: Lysosquilla sp.; 11: Upeneus parvus whereas the largest sharks ate the smallest prey (Fig. 7). The CV of prey $\mathrm{BD}$ also decreased with larger sharks $(\mathrm{B}=0.29, \mathrm{C}=0.28)$ relative to the smallest sharks $(\mathrm{A}=0.33)$.

\section{DISCUSSION}

Overall, Atlantic angel sharks Squatina dumeril ate mostly demersal teleost fishes, especially croakers, goatfishes, and butterfishes. Squid and crustaceans were also important prey for angel sharks of all sizes and during all seasons, though there were seasonal and size-related differences. Based on the average of Levin's standardized niche breadth value of 0.49 , and results from a previous study on the prey selectivity of Atlantic angel sharks (Baremore et al. 2008), these sharks fall in the mid-range of the specialist-generalist category, though their niche breadth becomes most narrow once they are mature.

The diet of the Atlantic angel shark is comparable to that of the angular angel shark Squatina guggenheim from the coast of Uruguay and Argentina (Vogler et al. 2003) and the ornate angel shark S. tergocellata off Australia (Bridge et al. 1998). The angular angel shark diet

\section{Prey size}

Gape of angel sharks was linearly related to their TL and was described by the equation gape $=0.1293 \times$ $\mathrm{TL}-1.8292\left(\mathrm{r}^{2}=0.92, \mathrm{p}<0.001\right)$. The maximum size of prey consumed increased with increasing shark size $(\mathrm{p}<0.001)$, although the relationship was weak $\left(\mathrm{r}^{2}=\right.$ 0.15; Fig. 5A). Even though the maximum sizes of prey eaten generally increased with increasing shark size, sharks of all sizes still consumed small prey. Most $(75.6 \%)$ prey consumed were $<30 \%$ of shark TL, and $95 \%$ of prey were $<40 \%$ of shark TL (Fig. 5B). The coefficient of variation (CV) of prey TL within each size class of angel sharks generally decreased with increasing size $(A=0.38, B=0.15, C=0.23)$. The relationship between prey $\mathrm{BD}$ and shark gape was best described by a log-log regression, which showed an increasing trend of larger prey eaten as gape increased $\left(\mathrm{r}^{2}=0.33\right.$; Fig. 6A). Sharks consumed prey with a BD $<60 \%$ of their gape most often $(\sim 70 \%$; Fig. $6 \mathrm{~B})$, and $95 \%$ of prey items were $<90 \%$ of shark gape. The smallest sharks ate the largest prey items (by relative prey BD), included sciaenids, gadids, and triglids, though the angular angel shark appeared to consume a higher frequency of pelagic fishes, like anchovy Engraulis anchoita and rough scad Trachurus lathami. Bridge et al. (1998) found that the ornate angel shark primarily ate arrow squid Notodarus gouldi, followed by fishes, mostly leatherjackets (Monacanthidae). Though similar to the diet of Atlantic angel sharks overall, Vogler et al. (2003) found that the trend in diet of angular angel shark was opposite, in that, cephalopods and crustaceans became more important in the diet of angular angel sharks with increasing size and the diet was less piscivorous and more diverse.

Atlantic angel sharks appear to exploit different prey resources depending on time of the year, with the importance of butterfish, squid, Atlantic croakers, and goatfishes changing with season. This was clear from the PCA biplots for Size Classes B and C, since the intermediate size class (B) sharks were influenced by different prey in all seasons, while the largest sharks (Size Class C) were highly influenced by butterfish in the spring and fall and squid in the winter. There were 


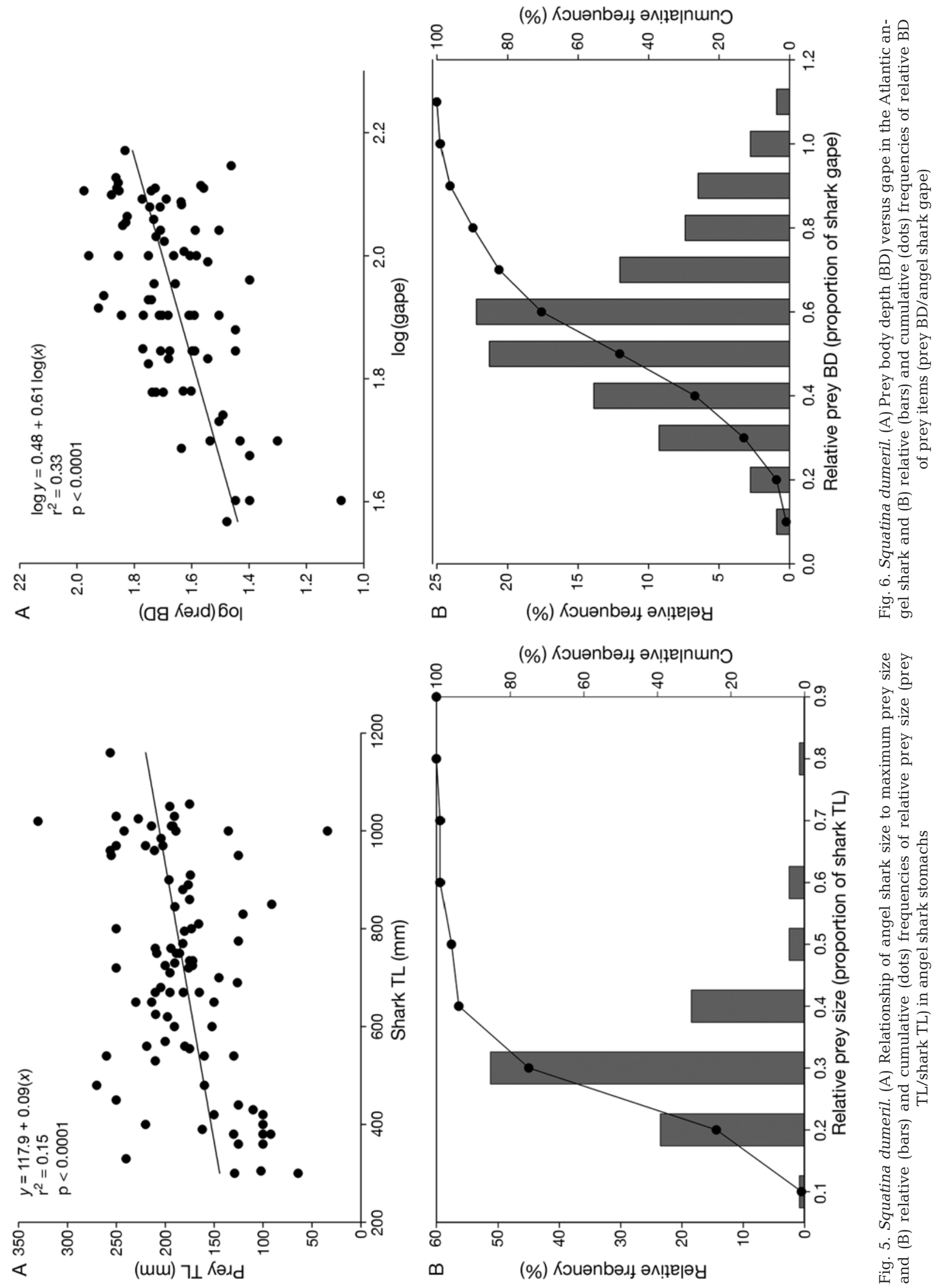




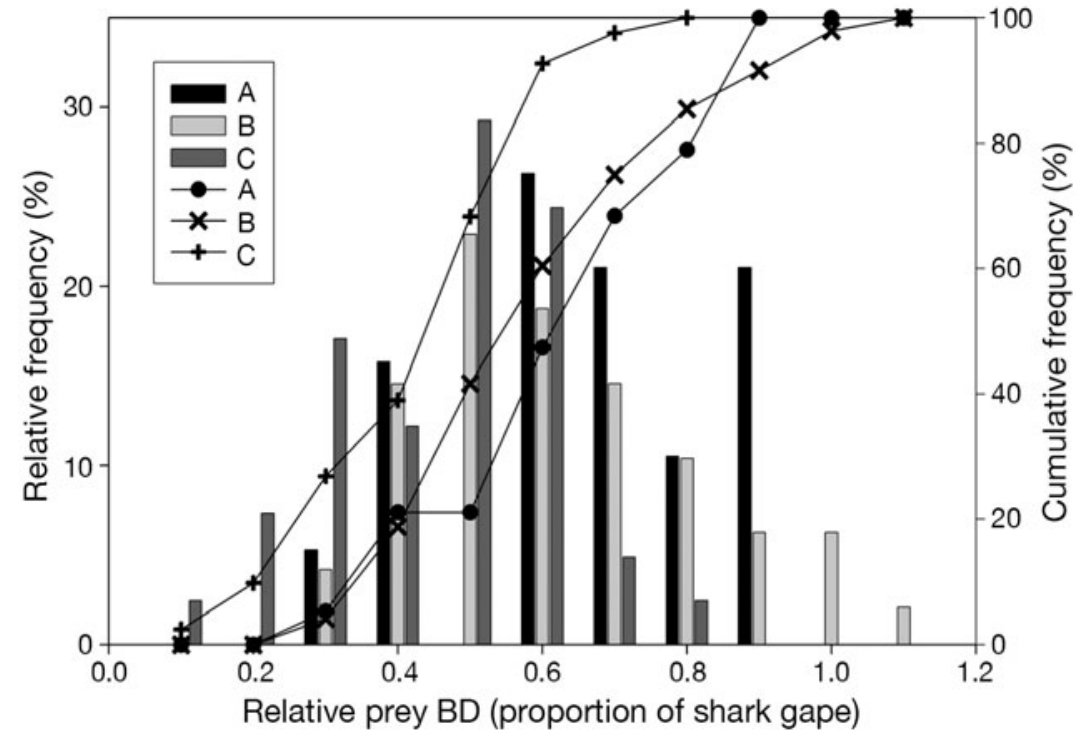

Fig. 7. Squatina dumeril. Relative (bars) and cumulative (symbols) frequencies of relative body depth (BD) of prey items (prey BD/angel shark gape) by shark size class (A < 500, B 500 to $800, C>800 \mathrm{~mm}$ TL)

most preferred prey size as predicted by optimal foraging theory. Gill (2003) further suggested that the relationship between prey size and gape may be more of an important factor in choice of prey than prey species. Our findings that the majority of angel sharks ate prey that was from 50 to $60 \%$ of their gape is consistent with Gill's (2003) hypothesis.

The CV values for both prey TL and BD decreased with increasing shark size, suggesting an increase in size selectivity. Small (Class A), mostly juvenile angel sharks, in particular, ate the largest prey in relation to their gape, presumably maximizing their energy intake per feeding event (Gill 2003). This, combined with juvenile fishes directing much of their energy intake to somatic growth, would allow them to become less vulnerable to predation and reach reproductive size comparatively

no marked seasonal differences for the smallest angel sharks (Size Class A). Sample size differences among the seasons could, however, have masked differences when compared with Size Classes B and C. It is unclear whether these seasonal differences in diet reflect a change in demersal fish community or are the result of natural variation in the diet of angel sharks. The broadening of niche breadth with season (winter through fall) could perhaps indicate a change in prey community during the year. Year-round sampling of potential prey at the appropriate depths (Baremore et al. 2008) is needed to determine whether that might occur.

Although the size of prey that angel sharks ate increased with shark size and gape, they still consumed relatively small prey. This is not uncommon as piscivores will select smaller size ranges of prey than predicted by optimal diet models (Juanes 1994). Scharf et al. (2000) showed statistically significant increases in the maximum sizes of prey items as predator size increased for 18 species of marine fishes, although there were increases in the maximum size of prey with size of predator for most (12 of 18) of those fishes. Bethea et al. (2004) similarly reported that finetooth shark Carcharhinus isodon and Atlantic sharpnose shark Rhizoprionodon terraenovae mostly ate relatively small prey in relation to the body size of the shark ( $<20 \%$ of body length), though larger prey were readily available in the study area.

Gill (2003) reported that prey that are $60 \%$ of the width of a piscivore's mouth provide the highest return for the lowest cost and that they should be the faster (Helfman et al. 1997). Because of physical limitations, such as gape and swimming speed, smaller predators are also exposed to fewer potential prey items than their larger conspecifics (Juanes 1994, Scharf et al. 2000). Consequently, it may benefit them to attack larger prey items when they are encountered (Gill 2003).

Species composition of demersal communities is stochastic, changing with season and diurnally with the daily migrations of many species of fishes, crustaceans, squids, and other invertebrates (Darnell 1990). Butterfish are known to be diurnal vertical migrators (Vecchione 1987), aggregating over the bottom during daylight hours and dispersing at night in surface waters. The high proportion of butterfish in the stomachs of the largest Atlantic angel sharks suggests that the sharks are not exclusively nocturnal feeders, similar to the behavior observed for Pacific angel sharks (Fouts \& Nelson 1999). Other common teleosts in the diet of angel sharks were Atlantic croakers, red goatfish, and longspine porgies, all of which are common demersal fishes in the waters of the northern Gulf of Mexico (Darnell 1990, McCormick 1995, McEachran \& Fechhelm 1998, 2005). Although these teleost species are mostly distributed in shallow waters of the continental shelf $(<100 \mathrm{~m})$, they have been reported in high abundance in waters as deep as $200 \mathrm{~m}$ (GSMFC 2002). There are some seasonal differences in abundance of resident demersal fishes, but these changes reflect inshore-offshore migrations (Darnell 1990). Squid are also known diurnal vertical migrators, moving into the upper water 
column at night and descending to the bottom during the day (NMFS 1999). The prevalence of squid in the diet of angel sharks, therefore, also suggests that angel sharks feed during the day. In contrast, the presence of cusk eels in the diet suggests that some night time feeding occurred as well, because cusk eels are nocturnal, burrowing during daylight hours (Darnell 1990, Retzer 1991).

Net feeding has been documented in sharks captured using gillnets (Bethea 2003). Gillnets are a passive gear, but the presence of fish caught in the net likely attracts sharks, which may become entangled as a result. Inclusion of the 16 completely undigested butterfish recovered in the stomachs of angel sharks would have caused butterfish to far outweigh all other prey species in terms of dietary importance, and would have narrowed the niche breadth of sharks in Size Class C from 0.44 to 0.26 . Most stomachs that contained butterfish that were coded 0 contained $>1$ butterfish in the same digestion state, a phenomenon that was rare in other stomachs. This occurrence, along with the observation of some angel sharks with several undigested fish in their mouths rather than their stomachs alone, suggests that either they were feeding in the nets or that fish were forced into the mouths of angel sharks while in the trawl. Given the morphology of the mouth, the wide esophagus, the fact that angel sharks are lie-and-wait predators, and the probable stress of capture, the latter explanation seems more feasible than the sharks actively feeding while in the trawl. While it is possible that these angel sharks ate the butterfish minutes before they were caught, we thought it prudent to exclude them from the analysis of food habits.

Angel sharks are top predators in the demersal communities of the Gulf of Mexico. Although they are ambush predators, their diet is dynamic and changes with size and season. This, along with apparent selectivity of prey (Baremore et al. 2008), would suggest that changes in prey species composition and size within the demersal community could have significant impacts on foraging of Atlantic angel sharks.

Acknowledgements. We thank D. Parkyn and M. Allen for their suggestions during the development of the present study and on previous versions of this manuscript. P. Rabaut, J. Sachs, K. Robinson, L. Hollensead, D. Bethea, and E. Leonard assisted with the processing of angel sharks and other samples associated with this study. Raffield's Fisheries provided all of the samples, and have been very helpful to us over the years. Financial and logistical support was provided by the Program of Fisheries and Aquatic Sciences, University of Florida, and the NOAA Fisheries Panama City Laboratory. All Atlantic angel sharks were collected with a NOAA Fisheries Service Exempted Fishing Permit (HMS-EFP-03-01, EFP-04-01, EFP-05-01).

\section{LITERATURE CITED}

Baremore IE (2007) Feeding ecology of the Atlantic angel shark in the northeastern Gulf of Mexico. MS, University of Florida, Gainesville, FL

Baremore IE, Murie DJ, Carlson JK (2008) Prey selection by the Atlantic angel shark Squatina dumeril in the northeastern Gulf of Mexico. Bull Mar Sci 82:297-313

> Berens EJ, Murie DJ (2008) Differential digestion and evacuation rates of prey in a warm-temperature grouper, gag Mycteroperca microlepis (Goode and Bean). J Fish Biol 72: 1406-1426

Bethea DM (2003) Foraging ecology of the early life stages of four shark species (Rhizoprionodon terraenovae, Carcharhinus limbatus, Carcharhinus isodon, and Carcharhinus brevipinna) in Apalachicola Bay, Florida. MS, North Carolina State University, Raleigh

Bethea DM, Buckel JA, Carlson JK (2004) Foraging ecology of the early life stages of four sympatric shark species. Mar Ecol Prog Ser 268:245-264

Brickle P, Laptikhovsky VV, Pompert J, Bishop A (2003) Ontogenetic changes in the feeding habits and dietary overlap between three abundant rajid species on the Falkland Islands' shelf. J Mar Biol Assoc UK 83:1119-1125

> Bridge NF, Mackay D, Newton G (1998) Biology of the ornate angel shark (Squatina tergocellata) from the Great Australia Bight. Mar Freshw Res 49:679-686

Brodziak J, Link JS (2002) Ecosystem-based fishery management: What is it and how can we do it? Bull Mar Sci 70:589-611

Browman HI, Stergiou KI (2004) Marine protected areas as a central element of ecosystem-based management: defining their location, size, and number. Mar Ecol Prog Ser 274:271-272

Cailliet GM, Mollet HF, Pittenger GG, Bedford D, Natanson LJ (1992) Growth and demography of the Pacific angel shark (Squatina californica), based upon tag returns off California. Aust J Mar Freshwater Res 43:1313-1330

> Cortés E (1999) Standardized diet compositions and trophic levels of sharks. ICES J Mar Sci 56:707-717

> Cortés E, Gruber SH (1990) Diet, feeding habits and estimates of daily ration of young lemon sharks, Negaprion brevirostris. Copeia 1990(1):204-218

Darnell RM (1990) Mapping of the biological resources of the continental shelf. Am Zool 30:15-21

Ebert DA (2002) Ontogenetic changes in the diet of the sevengill shark. Mar Freshw Res 53:517-523

> Ellis JR, Pawson MG, Shackley SE (1996) The comparative feeding ecology of six species of shark and four species of ray (Elasmobranchii) in the north-east Atlantic. J Mar Biol Assoc UK 76:89-106

FAO (Food and Agricultural Organization) (2002) Species identification for fishery purposes. The living marine resources of the western Central Atlantic. FAO, Rome

FAO (2003) Fisheries management 2. The ecosystem approach to fisheries. FAO, Rome

Ferry LA, Cailliet GM (1996) Sample size and data analysis: Are we characterizing and comparing diet properly? In: MacKinlay D, Shearer K (eds) GUTSHOP '96: feeding ecology and nutrition in fish. AFS, San Francisco State University, San Francisco, CA, p 71-80

Fouts WR, Nelson DR (1999) Prey capture by the Pacific angel shark, Squatina californica: visually mediated strikes and ambush-site characteristics. Copeia 1999:304-312

Gill A (2003) The dynamics of prey choice in fish: the importance of prey size and satiation. J Fish Biol 63:105-116 Gordon BL (1956) The amazing angel shark. Bull Int Ocean- 
ogr Found 2:109-111

Greene CH (1986) Patterns of prey selection: implications of predator foraging tactics. Am Nat 128:824-839

GSMFC (Gulf States Marine Fisheries Commission) (2002) SEAMAP environmental and biological atlas of the Gulf of Mexico. GSMFC, Ocean Springs, MS

Hambright KD (1994) Morphological constraints in the piscivore-planktivore interaction: implications for the trophic cascade hypothesis. Limnol Oceanogr 39:897-912

He R, Weisberg RH (2002) West Florida shelf circulation and temperature budget for the spring transition, 1999. Cont Shelf Res 22:719-748

Helfman GS, Collette BB, Facey DE (1997) The diversity of fishes. Blackwell Publishing, Malden, MA

Hyslop EJ (1980) Stomach contents analysis-review of methods and their application. J Fish Biol 17:411-429

Jobling M, Breiby A (1986) The use and abuse of fish otolith in studies of feeding habits of marine piscivores. Sarsia 71:265-274

Juanes F (1994) What determines prey size selectivity in piscivorous fishes? University of South Carolina Press, Columbia, SC

Juanes F, Buckel JA, Scharf FA (2001) Predatory behaviour and selectivity of a primary piscivore: comparison of fish and non-fish prey. Mar Ecol Prog Ser 217:157-165

Krebs CJ (1999a) Ecological methodology, 2nd edn. AddisonWesley Longman, Menlo Park, CA

Krebs CJ (1999b) Ecological methodology v.5.1 software. Department of Zoology, University of British Columbia, Vancouver. Available at: http://nhsbig.inhs.uiuc.edu/wes/ krebs.html

Lowe CG, Wetherbee BM, Crow GL, Tester AL (1996) Ontogenetic dietary shifts and feeding behavior of the tiger shark, Galeocerdo cuvier, in Hawaiian waters. Environ Biol Fishes 47:203-211

McCormick MI (1995) Fish feeding on mobile benthic invertebrates: influence of spatial variability in habitat associations. Mar Biol 121:627-637

McEachran JD, Fechhelm JD (1998) Fishes of the Gulf of Mexico, Vol 1. University of Texas Press, Austin

McEachran JD, Fechhelm JD (2005) Fishes of the Gulf of Mexico, Vol 2. University of Texas Press, Austin

Murie DJ (1995) Comparative feeding ecology of two sympatric rockfish congeners, Sebastes caurinus (copper rockfish) and $S$. malinger (quillback rockfish). Mar Biol 124: 341-353

Editorial responsibility: Brent Stewart,

San Diego, California, USA
Murie DJ, Lavigne DM (1985) A technique for recovery of otoliths from stomach contents of piscivorous pinnipeds. J Wildl Manag 49:910-912

Natanson LJ, Cailliet GM (1986) Reproduction and development of the Pacific angel shark, Squatina californica, off Santa Barbara, California. Copeia 1986:987-994

Natanson LJ, Cailliet GM (1990) Vertebral growth zone deposition in Pacific angel sharks. Copeia 1133-1145

NMFS (National Marine Fisheries Service) (1999) Longfin inshore squid, Loligo pealeii, life history and habitat characteristics. Essential Fish Habitat Source Document, NOAA Tech Mem NMFS-NE-146, NOAA, US Department of Commerce, Washington, DC

Pinkas L, Oliphant MS, Iverson ILK (1971) Food habits of albacore, bluefin tuna and bonito in Californian waters. Calif Fish Game 152:1-105

Retzer ME (1991) Life-history aspects of four species of cusk eels from the northern Gulf of Mexico. Copeia 1991(3): $703-710$

Robins CR, Carleton GC (1986) Peterson's field guide to Atlantic coast fishes of North America, Series 32. Houghton Mifflin Company, New York

Scharf FS, Juanes F, Rountree RA (2000) Predator size-prey size relationships of marine fish predators: interspecific variation and effects of ontogeny and body size on trophicniche breadth. Mar Ecol Prog Ser 208:229-248

Shepherd TD, Myers RA (2005) Direct and indirect fishery effects on small coastal elasmobranchs in the northern Gulf of Mexico. Ecol Lett 8:1095-1104

Stillwell CE, Kohler N (1982) Food, feeding habits, and estimates of daily ration of the shortfin mako (Isurus oxyrinchus) in the northwest Atlantic. Can J Fish Aquat Sci 39:407-414

Vecchione M (1987) Commercial fishing for gulf butterfish, Peprilus burti, in the Gulf of Mexico. Mar Fish Rev 49: $14-22$

Vogler R, Milessi AC, Quinones RA (2003) Trophic ecology of Squatina guggenheim on the continental shelf off Uruguay and northern Argentina. J Fish Biol 62:1254-1267

Williams AB (1984) Shrimps, lobsters, and crabs of the Atlantic coast of the eastern United States, Maine to Florida. Smithsonian Institution Press, Washington, DC

Yodzis P (1994) Predator-prey theory and management of multispecies families. Ecol Appl 4:51-58

Zar JH (1984) Biostatistical analysis. Prenice-Hall Inc., Englewood Cliffs, NJ

Submitted: October 1, 2008; Accepted: November 23, 2009

Proofs received from author(s): December 30, 2009 